\title{
Technology Roadmaps for the Determination of Technologies Used in Solar Photovoltaic Water Pumping Systems
}

\author{
Elquin B. Mejía ${ }^{\# 1}$, Esmerlis Camargo ${ }^{* 2}$, Carlos E. Robles ${ }^{* 3}$, Tomás González ${ }^{* 4}$, Jesús A. Rodriguez ${ }^{\$ 5}$ \\ ${ }^{*}$ Renewable energy program, SENA, Riohacha, Guajira, Colombia \\ 1emejiasu@misena.edu.co \\ * Industries and Alternative Energy Center, SENA, Riohacha, Guajira, Colombia \\ 2 ecamargot@sena.edu.co \\ 3 croblesp@sena.edu.co \\ 4 tgonzalezp@sena.edu.co \\ $\$$ Independent researcher, Cartagena, Bolívar, Colombia \\ 5 jarh1992@gmail.com
}

\begin{abstract}
This document uses the prospective technique Technology roadmaps for the determination of technologies used in solar photovoltaic water pumping systems (SPWPS) (submersible) in the department of Guajira, Colombia. The methodology was descriptive qualitative non-experimental. Under the criterion of the population census, seven professional engineers of the Industrial Center and alternative energies of the National Apprenticeship Service - SENA Regional Guajira were selected as a study sample. The data collection was done through the Technology roadmaps technique, with which suppliers and components for SPWPS were obtained through experts. In the analysis and results, suitable equipment was found in an SPWPS under the specific conditions of the region under study. The conclusions indicate that the Technology roadmaps technique provided the ideal tools in technology (solar panels, controllers, motors and pumps, among other devices), for an SPWPS under the geographic and climatic conditions of the region of La Guajira, besides qualifying the data as suitable for further research on the subject.
\end{abstract}

Keyword - Renewable Energy, Water Pumping, Performance, Technology, Electricity

\section{INTRODUCTION}

In Colombia, the department of La Guajira is characterized among many factors by its arid territory, warm climate and the level of solar radiation $(5.5-6 \mathrm{kWh} / \mathrm{m} 2)$ [1]. These conditions make the department in question a potential site for the use of renewable energies such as solar photovoltaic solar panels [2], which is useful to meet the basic needs of man who depend on electricity. A special implementation, used in the region, are solar photovoltaic water pumping systems (SPWPS) [3], which have been specially focused on communities far from urban centers and with difficult access to public services, such as communities Wayuu located in rancherías [4] or small groups of houses that hold families of the same kind by maternal line and are scattered in the geographic landscape close to the water wells [5].

SPWPS are a cost-effective alternative compared to conventional pumping systems, especially in isolated areas of non-developed countries [6]. Before being implemented, modeling, reliability, feasibility, field performance, design procedures and control strategies are often analyzed, among other details [7], to ensure a safe and efficient installation, as well as to identify those components and equipment that fits into the geographical area where the system will be implemented, in other words, perform the dimensioning [8] [9] taking into account the availability of technologies in the market.

In the city of Riohacha and its surroundings, the Industrial Center and alternative energies of the National Apprenticeship Service - SENA Regional Guajira, Colombia, has the Technical Program in Maintenance and Installation of Photovoltaic Solar Systems, in which apprentices are instructed in the installation and maintenance of these systems, however, the choice of technologies and equipment used to carry out the projects is based on the concept and expertise of the instructors, a fact that represents a limit in the performance of the systems before the possibility of not opting by the relevant equipment for pumping, either by cost, efficiency [10] or relevance to the characteristics of the region [11], among other factors. Therefore, the present document uses the prospective technique Technology roadmaps for the determination of technologies used in SPWPS (submersible) in the department of La Guajira, Colombia. 


\section{Methodology}

The methodology used was of a descriptive type, due to the objective and precise details of the characteristics of each component in the SPWPS [12]; qualitative, for providing an overview of the range of non-numerical characteristics in equipment [13]; not experimental, because of not manipulating the data obtained from the objective elements [14].

\section{A. Population}

Among the instructors teachers in the area, seven professional engineers from the Industrial Center and alternative energies of the National Apprenticeship Service were found - SENA Regional Guajira, Colombia. Therefore, under the population census criterion, the entire population of teachers was selected as a sample (Table 1).

TABLE I. Teachers members of the sample

\begin{tabular}{|c|l|c|}
\hline \multicolumn{1}{|c|}{ Profession } & \multicolumn{1}{|c|}{ Function } & Amount of people \\
\hline Mechanical Engineering & $\begin{array}{l}\text { Structure design, panel mounting, hydraulic sizing } \\
\text { (pump power, flow to be handled, hydraulic pipe }\end{array}$ & 3 \\
\hline Electronic Engineering & $\begin{array}{l}\text { Photovoltaic sizing, photovoltaic matrix, installation } \\
\text { of controllers and sensors, pump wiring. }\end{array}$ & 3 \\
\cline { 1 - 2 } Electrical engineer & & 7 \\
\hline Total & & 7 \\
\hline
\end{tabular}

Then, with the help of the previous ones, suppliers of equipment and supplies for SPWPS were selected.

\section{B. Data collection}

The collection was carried out using the Technology roadmaps technique, present in the platform and web tool for prospective studies Softprosp [15], in which the teachers of Table 1 (experts) were consulted, regarding each technology in the SPWPS and provider thereof.

\section{Data collection}

The data collected from the technologies were organized under different parameters such as purchase cost, maintenance and other factors. From the above, by means of consulting the experts, the appropriate equipment was identified in an SPWPS under specific conditions such as geographical, meteorological and economic conditions in the region of Riohacha, La Guajira, Colombia.

\section{Research procedure}

For the collection and subsequent analysis of data, a scheme was designed with steps that would make the research a systematic and orderly process (Figure 1).
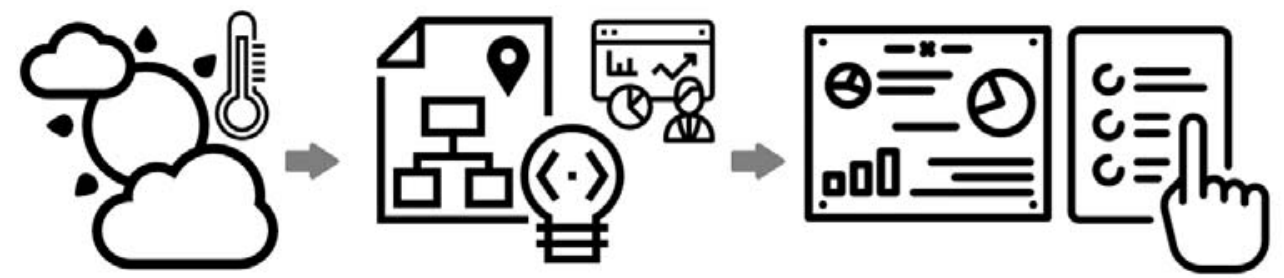

Fig. 1: scheme outlined

The proposed steps were:

1. Determination of environmental conditions

2. Technology roadmaps technique application to collect information of equipment present in an SPWPS by consulting teachers and suppliers

3. Data ordering and equipment selection for an SPWPS 


\section{III.RESULTS}

\section{A. 1. Determination of environmental conditions}

The present study was carried out in the region of Riohacha, La Guajira, Colombia, which is characterized by its arid territory, high temperatures and solar radiation, as shown in Figure 2 [16].

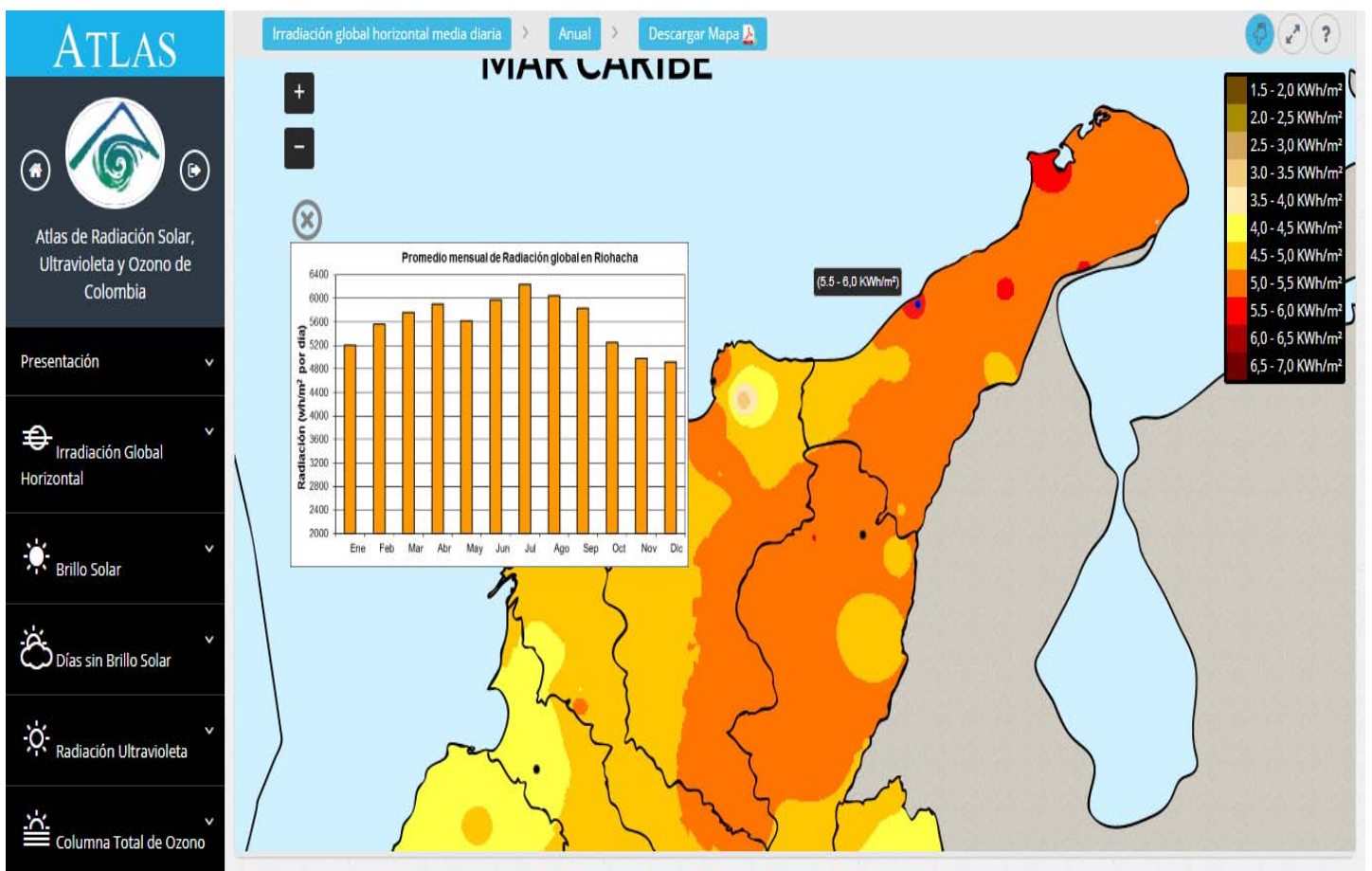

Fig. 2: Atlas of solar radiation, IDEAM

B. 2. Technology roadmaps technique application to collect information of equipment present in an SPWPS by consulting teachers and suppliers

By means of consulting the experts, through the Technology roadmaps technique present in the Softprosp web platform (Figure 3), together with the help of the single line diagram designed in the Franklin Electric application (Figure 4), it was determined that the fundamental components in the system (of a critical nature and greater importance). Were:

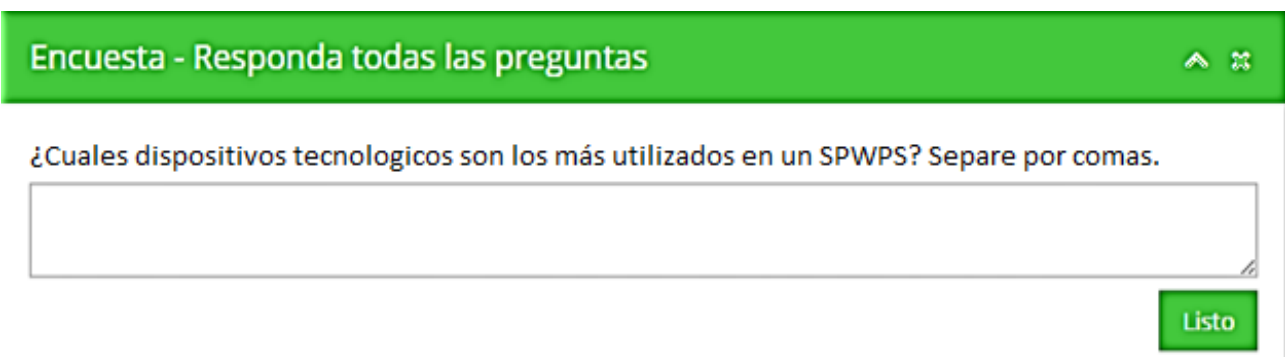

Fig. 3: Survey, Softprosp platform 


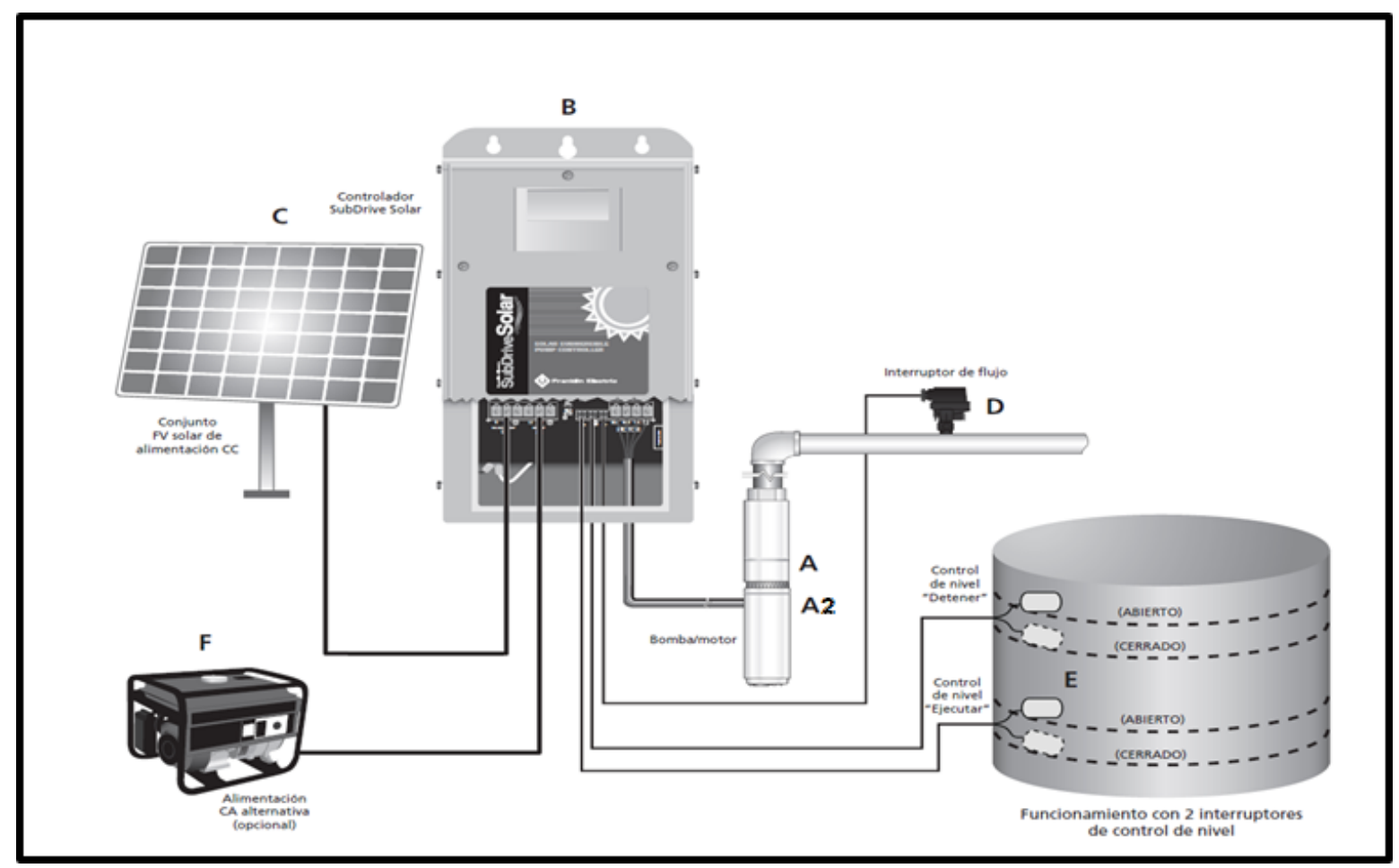

Fig. 4: Single line diagram, SPWPS
a. Motor
a2. Water Pump
b. Controller
c. Solar panels
d. Flow switch
e. Water level sensors (Upper / lower)
f. AC electric generators

Then, with the help of the Softprosp search engine, equipment suppliers were searched (Figure 5), from which those that showed the most benefits were selected based on criteria over time: technology, supply time, prices, product quality. The selected providers are shown in Table 2.

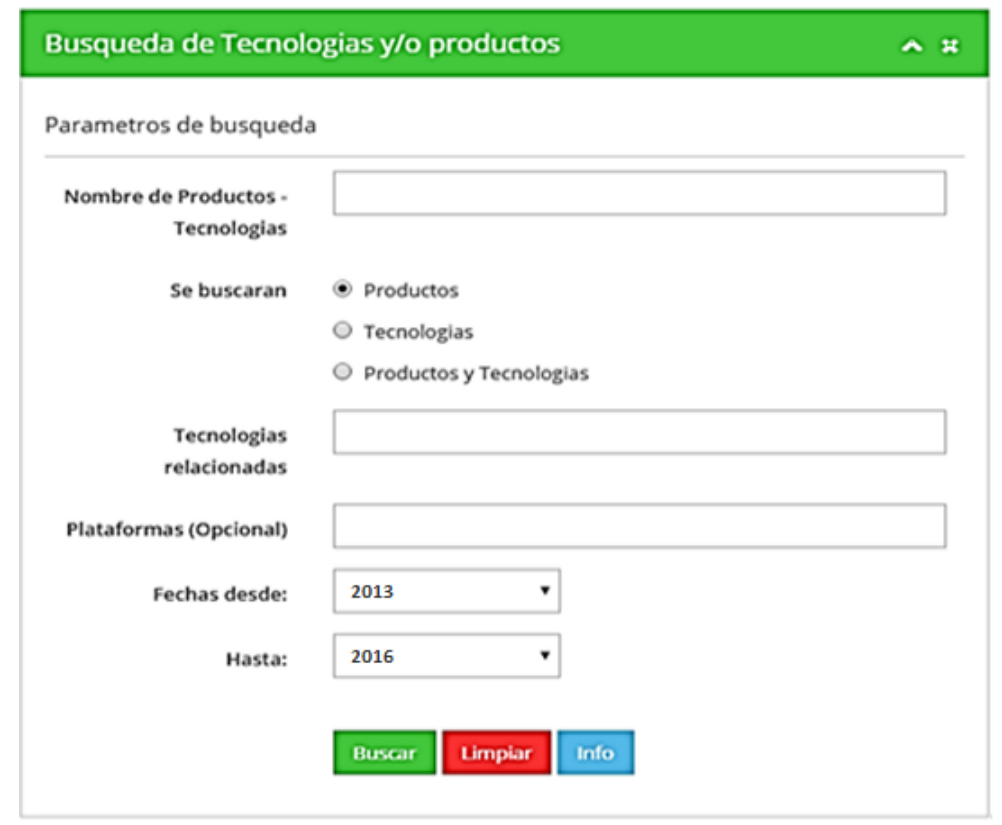

Fig. 5: Searching interface 
TABLE II. Equipment suppliers for SPWPS

\begin{tabular}{|c|c|c|c|c|c|c|c|}
\hline & \multicolumn{7}{|c|}{ Technology } \\
\hline Supplier & A & A2 & B & C & D & E & F \\
\hline 1 & $\mathrm{x}$ & $\mathrm{x}$ & $\mathrm{x}$ & & & & \\
\hline 2 & $\mathrm{x}$ & $\mathrm{x}$ & $\mathrm{x}$ & $\mathrm{x}$ & $\mathrm{x}$ & & \\
\hline 3 & & $\mathrm{x}$ & $\mathrm{x}$ & $\mathrm{x}$ & & $\mathrm{x}$ & \\
\hline 4 & & $\mathrm{x}$ & $\mathrm{x}$ & $\mathrm{x}$ & & & \\
\hline 5 & & & & & & & $\mathrm{x}$ \\
\hline 6 & & & & & & & $\mathrm{x}$ \\
\hline 7 & & & & & & & $\mathrm{x}$ \\
\hline 8 & & & & & & $\mathrm{x}$ & \\
\hline 9 & & & & & & $\mathrm{x}$ & \\
\hline
\end{tabular}

With the above, for each selected provider, the characteristics of each of the main technologies in the SPWPS could be determined (Table 3 to Table 9).

TABLE III. Motor offer

\begin{tabular}{|c|c|c|c|c|}
\hline Supp. & Name & Specifications & \$ (USD) & Warranty \\
\hline 1 & $\begin{array}{l}\text { 4" MCIP } 100 \\
\text { submersible } \\
\text { motor }\end{array}$ & $\begin{array}{c}0.5 / 7.5 \mathrm{HP} \\
30^{\circ} \approx 35^{\circ} \mathrm{C} \\
370 / 5500 \mathrm{~W}\end{array}$ & $\begin{array}{l}\text { Requested for quotation, } \\
\text { not visible to the public }\end{array}$ & $\mathrm{DK} / \mathrm{NA} / \mathrm{REF}$ \\
\hline 2 & $\begin{array}{l}\text { Motor Franklin } \\
\text { Electric }\end{array}$ & $\begin{array}{c}\text { Pmax: } 0.75 \mathrm{HP} \\
-15^{\circ} \approx 60^{\circ} \mathrm{C} 5500 \mathrm{~W}\end{array}$ & $\begin{array}{l}\text { Requested for quotation, } \\
\text { not visible to the public }\end{array}$ & DK/NA/REF \\
\hline
\end{tabular}

TABLE IV. Water pump offer

\begin{tabular}{|c|c|c|c|c|}
\hline Supp. & Name & Specifications & \$ (USD) & Warranty \\
\hline 1 & $\begin{array}{l}\text { Submersible } \\
\text { Pumps - QF } \\
\text { Series }\end{array}$ & $\begin{array}{l}\text { Head }(\mathrm{H}): \text { Max. } 660 \mathrm{~m} \\
0.5 / 335 \mathrm{HP} 0^{\circ} \approx 60^{\circ} \mathrm{C} . \\
\text { Max flow: } 440 \mathrm{~m}^{3} / \mathrm{hr} \\
\text { Max } 7333 \mathrm{LPM}\end{array}$ & $\begin{array}{c}\text { Requested for } \\
\text { quotation, not visible } \\
\text { to the public }\end{array}$ & DK/NA/REF \\
\hline \multirow{2}{*}{2} & $\begin{array}{c}\text { Bomba solar NPT } \\
\text { 25SDSP-1.5HP }\end{array}$ & $\begin{array}{c}\text { GPM: } 25 \\
1.5 \mathrm{HP}-200-300 \\
400 / 2000 \mathrm{~W}\end{array}$ & \multirow{2}{*}{$\begin{array}{l}\text { Requested for } \\
\text { quotation, not visible } \\
\text { to the public }\end{array}$} & \multirow{2}{*}{$\mathrm{DK} / \mathrm{NA} / \mathrm{REF}$} \\
\hline & $\begin{array}{c}\text { Bomba solar NPT } \\
\text { 25SDSP-3.0HP }\end{array}$ & $\begin{array}{c}\text { GPM: } 25 \\
\text { 200/325V-3.0HP } \\
\text { 750/3500W }\end{array}$ & & \\
\hline 3 & Solar water pump & $750 \mathrm{~W}-220 \mathrm{~V}-50 \mathrm{~Hz}$ & $\begin{array}{c}\text { Solar submersible } \\
\text { pump system } \\
\$ 1000-10000\end{array}$ & 2 years \\
\hline 4 & $\begin{array}{c}\text { FSC3 Solar } \\
\text { Centrifugal Pump }\end{array}$ & $\begin{array}{c}\text { Max Flow }(\mathrm{M} 3 / \mathrm{H}) 5 \approx 7 \\
\text { Max Head }(\mathrm{m}) \\
30 \approx 180 \mathrm{~m} \\
\text { Outlet }(\mathrm{IN}): 1.25^{\prime \prime} \\
270 \mathrm{~W}\end{array}$ & $\begin{array}{l}\text { Requested for } \\
\text { quotation, not visible } \\
\text { to the public }\end{array}$ & DK/NA/REF \\
\hline
\end{tabular}


TABLE V. Controller offer

\begin{tabular}{|c|c|c|c|c|}
\hline Supp. & Name & Specifications & \$ (USD) & Warranty \\
\hline 1 & $\begin{array}{c}\text { Single Phase - } \\
\text { SCU200 }\end{array}$ & $\begin{array}{c}0.37 / 3700 \mathrm{~W} \\
0.5 / 5 \mathrm{HP} \\
220 \mathrm{~V}-50 \mathrm{HZ}\end{array}$ & $\begin{array}{c}\text { Requested for quotation, } \\
\text { not visible to the public }\end{array}$ & DK/NA/REF \\
\hline 2 & $\begin{array}{c}\text { CONTROL BOX, } \\
\text { STANDARD }\end{array}$ & $\begin{array}{c}230 \mathrm{~V}-60 \mathrm{~Hz}- \\
5 \mathrm{HP}\end{array}$ & $\begin{array}{c}\text { Included in SubDrive } \\
\text { SolarPAK }\end{array}$ & DK/NA/REF \\
\hline 3 & $\begin{array}{c}\text { Solar controller } \\
\text { system (PLC) }\end{array}$ & $\begin{array}{c}10^{\circ} \approx 50^{\circ} \mathrm{C} \\
1500 \mathrm{~W}-220 \mathrm{~V}\end{array}$ & $\begin{array}{c}\text { Solar submersible pump } \\
\text { system } \$ 1000-10000\end{array}$ & DK/NA/REF \\
\hline 4 & $\begin{array}{c}\text { Mppt controller } \\
\text { for pump }\end{array}$ & $110 / 220 \mathrm{~V}$ & $\begin{array}{c}\text { Requested for quotation, } \\
\text { not visible to the public }\end{array}$ & DK/NA/REF \\
\hline
\end{tabular}

TABLE VI. Solar panels offer

\begin{tabular}{|c|c|c|c|c|}
\hline Supp. & Name & Specifications & \$ (USD) & Warranty \\
\hline 2 & $\begin{array}{l}\text { Solar panel } \\
\text { (SubDrive } \\
\text { SolarPAK) }\end{array}$ & $\begin{array}{c}\text { Efic Max: } 16.05 \% \\
-60^{\circ} \approx 85^{\circ} \mathrm{C} \text { Pmax: } 260 \mathrm{~W} \\
\text { Vmp: } 30.2 \mathrm{~V} \text { Voc: } 37.4 \mathrm{~V}\end{array}$ & $\begin{array}{l}\text { Included in SubDrive } \\
\text { SolarPAK } \$ 270\end{array}$ & No \\
\hline \multirow{2}{*}{3} & Mono solar panel & $\begin{array}{c}\text { Pmax: } 340 \mathrm{~W} \\
\text { Vmp: 37.9V Voc: } 46.76\end{array}$ & $\begin{array}{c}\text { Solar submersible } \\
\text { pump system } \$ 1000- \\
10000\end{array}$ & \multirow{2}{*}{10 years } \\
\hline & Poly solar panel & $\begin{array}{c}\text { Pmax: 300W } \\
\text { Vmp: 36.3V Voc: } 44.8\end{array}$ & $\begin{array}{c}\text { Solar submersible } \\
\text { pump system } \$ 1000- \\
10000\end{array}$ & \\
\hline 4 & $\begin{array}{l}\text { Poly-Crystalline } \\
\text { Solar Module }\end{array}$ & $\begin{array}{c}\text { Pmax: } 290 \approx 320 \mathrm{~W} \\
\text { Vmp: } 35.9 \text { Voc: } 44.5\end{array}$ & $\begin{array}{c}\text { Requested for } \\
\text { quotation, not visible to } \\
\text { the public }\end{array}$ & 10 years \\
\hline
\end{tabular}

TABLE VII. Flow switch offer

\begin{tabular}{|c|c|c|c|c|}
\hline Supp. & Name & Specifications & \$ (USD) & Warranty \\
\hline & & ${ }^{\circ}$ C-bar-psi & & \\
& & $20-18-261$ & Included in SubDrive & \multirow{2}{*}{ DK/NA/REF } \\
2 & \multirow{2}{*}{ F21 } & $25-15.75-228$ & SolarPAK & \\
& & $30-13.5-196$ & & \\
& & $35-11.25-163$ & & \\
\hline
\end{tabular}

TABLE VIII. Water level sensors (Upper / lower) offer

\begin{tabular}{|c|c|c|c|c|}
\hline Supp. & Name & Specifications & $\$($ USD) & Warranty \\
\hline 3 & Water level switch & DK/NA/REF & $\begin{array}{c}\text { Solar submersible pump } \\
\text { system } \$ 1000-10000\end{array}$ & 2 years \\
\hline 8 & $\begin{array}{c}\text { Sensor Horizontal } \\
\text { de Nivel de Agua }- \\
\text { Flotador Interruptor }\end{array}$ & $\begin{array}{c}-10 \approx 85^{\circ} \mathrm{C} \\
70 \mathrm{~W}-110 \mathrm{~V}-0.5 \mathrm{~A}\end{array}$ & $\$ 6.7$ & DK/NA/REF \\
\hline 9 & $\begin{array}{c}\text { Sensor para tanque } \\
\text { Float switch }\end{array}$ & $\begin{array}{c}-30 \approx 125^{\circ} \mathrm{C} \\
10 \mathrm{~W}- \\
110 \mathrm{~V} / 220 \mathrm{~V}-0.5 \mathrm{~A}\end{array}$ & $\$ 22$ & DK/NA/REF \\
\hline
\end{tabular}


TABLE IX. AC electric generators offer

\begin{tabular}{|c|c|c|c|c|}
\hline Supp. & Name & Specifications & $\$($ USD) & Warranty \\
\hline 5 & Gasoline electric generator & $\begin{array}{c}2500 \mathrm{~W}-110 / 220 \mathrm{~V} \\
3100 \mathrm{~W}-110 / 220 \mathrm{~V}\end{array}$ & $\$ 396 \$ 656$ & DK/NA/REF \\
\hline 6 & $\begin{array}{c}\text { Electric generator } \\
\text { YAMAHA EF2600FW }\end{array}$ & $\begin{array}{c}2600 \mathrm{~W}- \\
120 \mathrm{VAC} / 12 \mathrm{VDC}\end{array}$ & $\begin{array}{c}\text { Requested for } \\
\text { quotation, not } \\
\text { visible to the public }\end{array}$ & DK/NA/REF \\
\cline { 2 - 5 } & $\begin{array}{c}\text { Power plant YAMAHA } \\
\text { EF7200DE }\end{array}$ & $7200 \mathrm{~W}-120 / 240 \mathrm{~V}$ & $\begin{array}{c}\text { Requester for } \\
\text { visible to the public }\end{array}$ & DK/NA/REF \\
\hline 7 & $\begin{array}{c}\text { GG2800 Bauker Gasoline } \\
\text { electric generator }\end{array}$ & $2400 \mathrm{~W}-110 \mathrm{~V}$ & $\$ 450$ & DK/NA/REF \\
\cline { 2 - 6 } & $\begin{array}{c}\text { Ducson Gasoline electric } \\
\text { generator }\end{array}$ & $3700 \mathrm{~W}-120 \mathrm{~V}$ & $\$ 960$ & DK/NA/REF \\
\hline
\end{tabular}

\section{3. Data ordering and equipment selection for an SPWPS}

Once the SPWPS elements offered by the suppliers were identified, those devices of ideal character for the system were selected. The above resulted in the results obtained in Table 10.

TABLE X. Items selected for the SPWPS

\begin{tabular}{|c|c|c|c|}
\hline Element & Supplier & Name & Characteristics \\
\hline Motor & 2 & Motor Franklin Electric & $\begin{array}{c}\text { Pmax: } 0.75 \mathrm{HP} \\
-15^{\circ} \approx 60^{\circ} \mathrm{C} 5500 \mathrm{~W}\end{array}$ \\
\hline Water pump & 2 & $\begin{array}{c}\text { Bomba solar NPT } \\
\text { 25SDSP-3.0HP }\end{array}$ & $\begin{array}{c}\text { GPM: } 25 \\
200 / 325 \mathrm{~V}-3.0 \mathrm{HP} 750 / 3500 \mathrm{~W}\end{array}$ \\
\hline Controller & 2 & $\begin{array}{c}\text { CONTROL BOX, } \\
\text { STANDARD }\end{array}$ & $230 \mathrm{~V}-60 \mathrm{~Hz}-5 \mathrm{HP}$ \\
\hline Solar panels & 2 & $\begin{array}{c}\text { Solar panel (SubDrive } \\
\text { SolarPAK) }\end{array}$ & $\begin{array}{c}\text { Efic Max: } 16.05 \% \\
-60^{\circ} \approx 85^{\circ} \mathrm{C} \text { Pmax: } 260 \mathrm{~W} \\
\text { Vmp: } 30.2 \mathrm{~V} \text { Voc: } 37.4 \mathrm{~V}\end{array}$ \\
\hline Flow switch & 2 & F21 & $\begin{array}{c}{ }^{\circ} \mathrm{C}-\mathrm{bar}-\mathrm{psi} 20-18-261 \\
25-15.75-22830-13.5-196 \\
35-11.25-163\end{array}$ \\
\hline $\begin{array}{c}\text { Water level sensors } \\
\text { (Upper / lower) }\end{array}$ & 9 & $\begin{array}{c}\text { Sensor para tanque } \\
\text { Float switch }\end{array}$ & $\begin{array}{c}-30 \approx 125 \\
{ }^{\circ} \mathrm{C} \\
10 \mathrm{~W}-110 \mathrm{~V} / 220 \mathrm{~V}-0.5 \mathrm{~A}\end{array}$ \\
\hline Electric generator & 5 & $\begin{array}{c}\text { Gasoline electric } \\
\text { generator }\end{array}$ & $\begin{array}{c}2500 \mathrm{~W}-110 / 220 \mathrm{~V} \\
3100 \mathrm{~W}-110 / 220 \mathrm{~V}\end{array}$ \\
\hline
\end{tabular}

For systems such as SPWPS, activities such as generating component installation models [16], how to select the technologies of these systems, are important factors because they influence the overall performance of photovoltaic systems [17]. In a similar way to the present investigation, in [18], an exhaustive review of the literature of solar pumping technology was carried out, from which it was obtained among the conclusions that the factors that affect performance techniques and improvement of efficiency, the use of highly efficient photovoltaic modules, including bifacial modules and the degradation of the photovoltaic generator are areas of research to reduce cost, improve performance and improve the service life of the pumping system, conclusions which adjust and complement the objective of the present investigation.

\section{IV.CONCLUSION}

Based on the results obtained, it is concluded that

- Technology roadmaps technique was effective in identifying suppliers and equipment with greater suitability to operate in an SPWPS under the conditions that the Riohacha region has, La Guajira.

- The data revealed in the present investigation can be useful for future sizing of SPWPS, an activity which is of great benefit because it allows to avoid energy leaks, prolong the useful life of the equipment and increase system performance, among other advantages. 


\section{REFERENCES}

[1] IDEAM, Atlas of solar radiation - IDEAM, Available: http://atlas.ideam.gov.co/visorAtlasRadiacion.html

[2] V. V. Tyagia, N. A. A. Rahim, N. A. Rahim, and J. A. L. Selvaraj, "Progress in solar PV technology: Research and achievement", Renewable and Sustainable Energy Reviews, vol. 20, pp. 443-461, 2013.

[3] V. C. Sontake and V. R. Kalamkar, "Solar photovoltaic water pumping system - A comprehensive review," Renewable and Sustainable Energy Reviews, vol. 59, pp. 1038-1067, 2016.

[4] J. Bonet-Morón and L. W. Hahn-De-Castro, "La mortalidad infantil en La Guajira: Una caracterización estructural," Documentos de trabajo sobre economía regional, issue 255, 2017.

[5] Available http://www.upme.gov.co/guia_ambiental/carbon/areas/minorias/contenid/wayuu.htm

[6] G. Li, Y. Jin, M. W. Akram, and X. Chen, "Research and current status of the solar photovoltaic water pumping system - A review," Renewable and Sustainable Energy Reviews, vol.79, pp. 440-458, 2017.

[7] D. H. Muhsen, T. Khatib, and F. Nagi, "A review of photovoltaic water pumping system designing methods, control strategies and field performance," Renewable and Sustainable Energy Reviews, vol. 68, part 1, pp. 70-86, 2017.

[8] Renu, B. Bora, B. Prasad, O.S. Sastry, A. Kumar, and M. Bangar, "Optimum sizing and performance modeling of Solar Photovoltaic (SPV) water pumps for different climatic conditions," Solar Energy, vol. 155, pp. 1326-1338, 2017.

[9] D. H. Muhsen, T. Khatib, and T. E. Abdulabbas, "Sizing of a standalone photovoltaic water pumping system using hybrid multicriteria decision making methods," Solar Energy, vol. 159, pp. 1003-1015, 2018.

[10] P. E. Campana, H. Li, J. Zhang, R. Zhang, J. Liu, and J. Yan, "Economic optimization of photovoltaic water pumping systems for irrigation," Energy Conversion and Management, vol. 95, pp. 32-41, 2015.

[11] I. Yahyaoui, A. Atieh, A. Serna, and F. Tadeo, "Sensitivity analysis for photovoltaic water pumping systems: Energetic and economic studies," Energy Conversion and Management, vol. 135, pp. 402-415, 2017.

[12] E. Babbie, The basics of social research, 5th ed. Belmont: Wadsworth Cengage Learning, 2011.

[13] N. Walliman, Research methods - the basics. Oxon, USA: Routledge, 2011.

[14] R. Kumar, Research methodology, a step by step guide for beginners, 3rd ed. SAGE, 2003.

[15] R. J. Martelo, L. Moncaris and L. Velez, "Integration of Regnier's Abacus, Brainstorming and Polls in the Definition of Key Variables for Prospective Studies,” Información tecnológica, vol. 27, no. 5, pp. 243-250, 2016

[16] I. Yahyaoui, Chapter 2 - Modeling of the Photovoltaic Irrigation Plant Components, In Specifications of Photovoltaic Pumping Systems in Agriculture, pp. 15-57. Elsevier: 2017.

[17] G. Dilep, and S. N. Singh, "Selection of non-isolated DC-DC converters for solar photovoltaic system," Renewable and Sustainable Energy Reviews, vol. 76, pp. 1230-1247, 2017.

[18] S.S. Chandel, M. Nagaraju and R. Chandel, "Review of solar photovoltaic water pumping system technology for irrigation and community drinking water supplies," Renewable and Sustainable Energy Reviews, vol. 49, pp. 1084-1099, 2015.

\section{AUTHOR PROFILE}

Elquin B. Mejía works as full-time professor at the SENA (Colombia). Mr. Mejía completed his postgraduate study from North University (Colombia). Mr. Mejía completed his undergraduate in Electronic Engineer and telecommunications at the El Bosque University.

Esmerlis Camargo works as Research leader SENNOVA at the SENA (Colombia). Mrs. Camargo completed her PhD. from Rafael Belloso Chacín University (Colombia). Mrs. Camargo completed her undergraduate in Industrial Engineering at the University of La Guajira.

Carlos E. Robles works as subdirector of the Industries and Alternative Energy Center at the SENA (Colombia). Mr. Robles completed his magister from Externado University of Colombia (Colombia). Mr. Robles completed his undergraduate in Industrial Engineering at the University of La Guajira.

Tomás González works as Researcher in the TECNOVA research group at the SENA (Colombia). Mr. González completed his undergraduate in Mechanical Engineering at the Malabi Technical University.

Jesús A. Rodríguez works as independent researcher (Colombia). Mr. Rodríguez completed his undergraduate in Systems Engineering at the University of Cartagena. 